\section{Sacrificial layers: an alternative for the conservation of the lime stuccos from Templo Mayor's Structure B in Mexico City}

\section{Camadas sacrificiais: uma alternativa para a conservação dos estuques de cal da Estrutura B do Templo Mayor na Cidade do México}

\section{ELISA CARMONA \\ VAILLARD}

Escuela Nacional de Conservación, Restauración y Museografía "Manuel del Castillo Negrete", Gral. Anaya 187, San Diego Churubusco, 04120 Ciudad de México, Mexico.

e.carmova@gmail.com

\begin{abstract}
Structure B is an archaeological structure from the post-classic period of the Mexica culture located within the archaeological site of Templo Mayor in Mexico City. The various alteration dynamics caused by its exposure to the weather have generated severe conservation problems in the stuccos that cover the reliefs of the stone skulls of Structure B. Since the alteration effects are mainly due to the crystallization of salts, the absorption of direct humidity because of stagnation of water and the impact of rainwater, the use of sacrificial layers is presented as a measure for the long-term conservation of the stuccos. This investigation proposes a methodological framework for the elaboration of diverse models of sacrificial layers, as well as for their qualitative evaluation after submitting them to resistance tests that imitate the environmental dynamics to which the structure is subjected, in order to design a suitable sacrificial layer for a given structure and context.
\end{abstract}

\section{Resumo}

A Estrutura B é uma estrutura arqueológica da cultura asteca, do período pós-clássico, localizada dentro do complexo arqueológico Templo Mayor na Cidade do México. A sua exposição às condições climatéricas locais tem originado vários problemas ao nível da conservação dos estuques que cobrem os relevos dos crânios de pedra da Estrutura B. Dado que os efeitos de alteração são causados maioritariamente pela cristalização de sais, pela absorção directa de água estagnada e pelo impacto da precipitação, o uso de camadas sacrificiais é aqui apresentado como uma medida para a conservação a longo prazo destes estuques. Assim, este trabalho propõe uma metodologia não só para a elaboração de diversos modelos de camadas sacrificiais, mas também para a avaliação qualitativa desses mesmos modelos, através da realização de ensaios de resistência que visam simular as condições climatéricas que podem afectar a estrutura em questão. Esta metodologia permite desta forma, conceber camadas sacrificiais específicas para uma determinada estrutura e respectivo contexto.

\section{KEYWORDS}

Mortar

Nopal mucilage

Void index

Weather exposure

Methodological evaluation Sacrificial layer

\section{PALAVRAS CHAVE}

Argamassa

Mucilagem do Nopal

Índice de vazios

Condições climatéricas

Metodologia de avaliação

Camadas sacrificiais 


\section{Introduction}

Structure B is an archaeological structure located in the northern courtyard of the Templo Mayor archaeological site, capital of what used to be the ancient Mexica Empire. The archaeological site was built on a region of high seismic activity, on a clayey and compressible soil, as it used to be an old lacustrine zone currently in the center of Mexico City [1]. This environment, in addition to the conditions of the soil after demolishing the surrounding buildings at the time of the excavation of the site between 1978 and 1982, caused the deformation of the ground triggering the inclination of the courtyards and the surrounding structures (amongst them Structure B), and the stagnation of rainwater [2].

Structure B is built from different types of igneous extrusive rocks. Some of the stones that make up the east, north and south facades are carved into the shape of skulls and covered with multiple layers of lime stucco. Due to its historical and geographical context, Structure B shows multiple conservation problems, both structural and of the architectural finishes. This study focuses only on the formulation of a sacrificial layer for the protection of the stuccos in Structure B, which are mainly affected by three alteration dynamics: salt crystallization (due to previous interventions carried out with cement), absorption of direct humidity due to stagnation of water (as a consequence of the deformation of the ground) and the impact of rainfall (due to weather exposure) (Figure 1).

The deformation of the ground generated fissures in Structure B, which were filled with concrete, a source of sulfates that in contact with water dissolve, migrate and crystallize inside the structure causing disintegration and the loss of the lime stuccos. In addition, the long-term natural agents such as the constant reception and absorption of water due to rainfall and the consequent evaporation of direct humidity through the architectural finishes, have caused differential erosion in the stuccos [2] (Figure 2).

Taking into account these alteration mechanisms, the use of sacrificial layers for the long-term preservation of the stuccos of Structure B was proposed since they represent a viable measure to provide mechanical, chemical and thermal protection against alteration factors caused by weather exposure, and act as an evaporation and salt crystallization surface area [3-4]. In addition, the sacrificial layers would contribute to the preservation of the perceptive relations that give cultural significance to the archaeological environment and will act as an alternative to invasive solutions such as roofs, as they interfere with the spatial perception of the archaeological site (Figure 3).
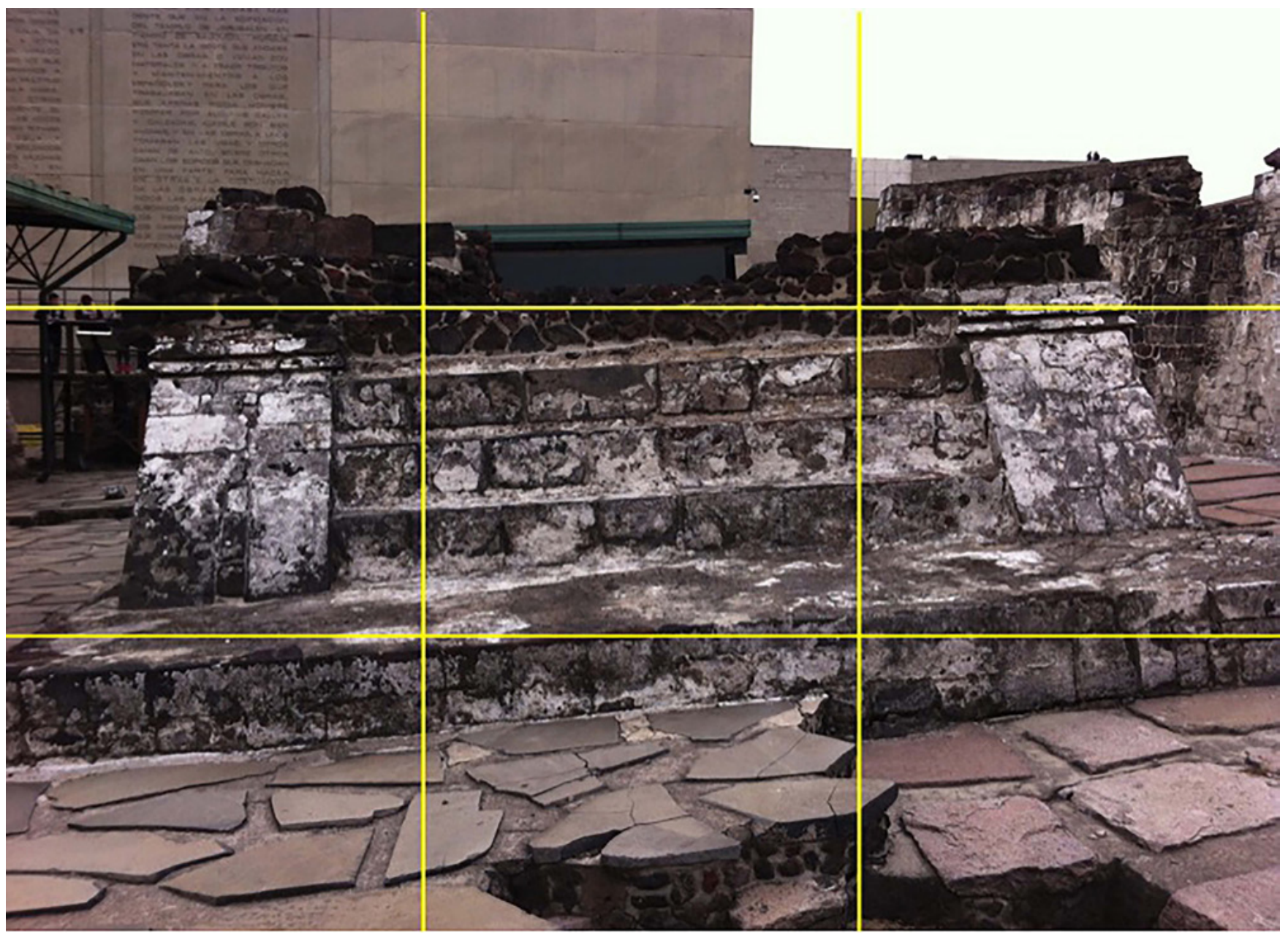

Figure 1. Inclination of the courtyards and Structure B. 


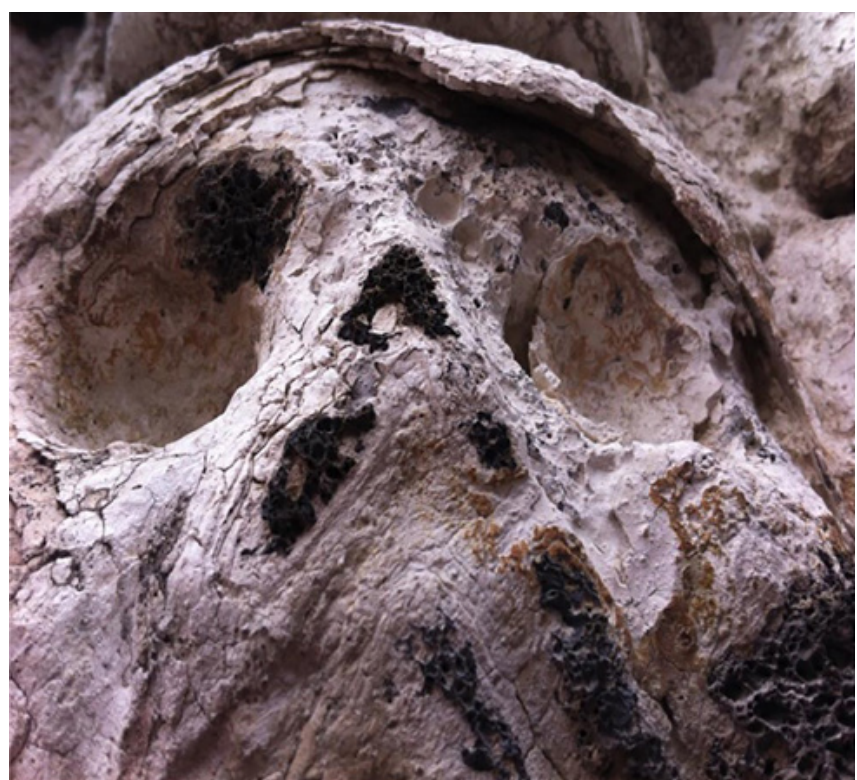

Figure 2. Structure B's stucco pathology example.

Based on the revised literature [5-27], in Mexico, sacrificial layers on archaeological structures have been used as stuccos, applied directly on stone materials, as sacrificial floors, as separation layers on re-burials and in the restitution of architectural finishes.

From the reviewed literature it was concluded that the effectiveness of a technique or materials used on the elaboration of a sacrificial layer for a particular site does not imply that it will show the same behavior on others. Thus, materials and techniques need to be adapted to the characteristics of each object or structure. Similarly, according to the experiences on the field, the use of materials different from the original has been counterproductive, so over time it has been chosen to formulate the sacrificiallayers with the same type of materials that make up the structure on which the sacrificial layer will be applied on, thus the results obtained from the field experience respond directly to the objectives of their application, the techniques and materials used, as well as to the environmental conditions and the materials on which they were applied upon.

Considering the conservation conditions and alteration dynamics affecting Structure B, in addition to the information obtained from the field experience on the use of sacrificial layers in Mexico, it was reckoned that the formulated sacrificial layer should have a greater capacity for water absorption compared to the underlying material and be highly porous and resistant in order to promote the migration of water and salt crystallization. In addition, its removal should not represent damages for the original materials. The characteristics of the materials proposed to constitute the sacrificial layers to test are presented next.

\section{Lime}

The sacrificial layer will be constituted by lime, since in addition to being a material observed on the original structure, it is characterized by its high capillarity and porosity, making it able to transfer the drying and crystallization areas from the original materials towards the sacrificial layer [4].

Amongst other characteristics and outstanding properties, lime mortars withhold high plasticity or malleability when fresh. They also present a slow setting process and thanks to their composition they do not represent a source of salts that could affect the structure. Likewise, they show a relatively high deformation capacity, which allows them to absorb movements produced in the underlying materials without cracking [28].

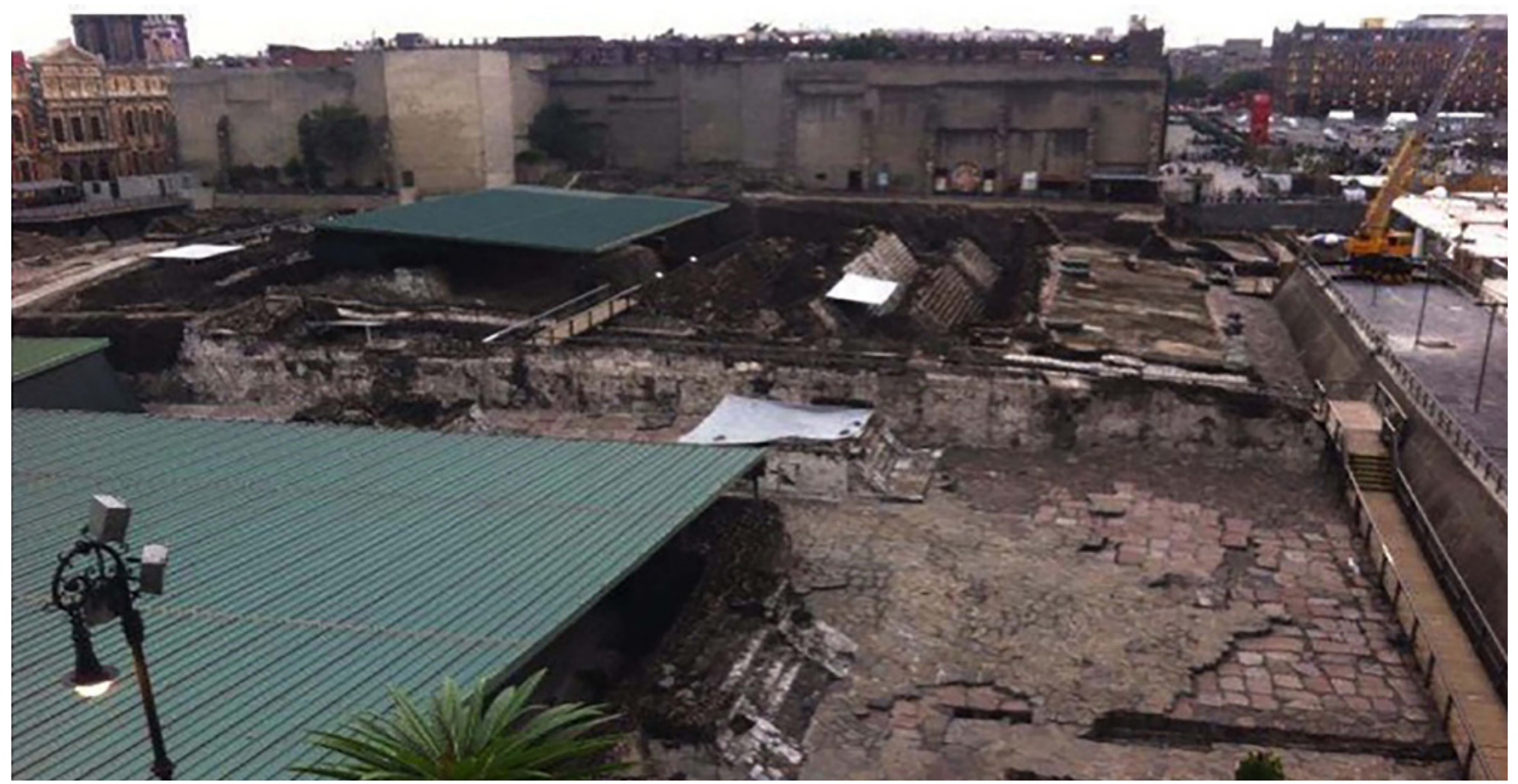

Figure 3. Interference of the spatial perception of the archaeological site due to the presence of roofs. 


\section{Aggregates}

The size, shape and distribution of the aggregates' particles play a fundamental role in the durability and cohesive properties of a mortar since they intervene in its functionality, resistance and permeability. In this aspect, an essential factor in obtaining a mortar with a good performance is the void index, which refers to the proportion of empty spaces in a given volume of aggregates [29].

In mortars with mixed granulometries the smallest particles occupy the remaining spaces between the large particles resulting in a stable mortar and with a low void index compared to that of a mortar with a singlegranulometry aggregates. A well-functioning mortar fills these spaces with lime in a balanced way, completely covering all the particles of the aggregates and achieving an optimal cohesion without excess lime, which could cause its contraction and therefore cracking. Measuring the void index of the aggregates allows adding the right proportion of lime to the mortar to make it cohesive and durable [30].

To determine the approximate value of the void index in a given volume of aggregates it is possible to place them in a graduated container and pour water until saturating it, then let it rest for an hour and if necessary, refill the volume of water until the water level matches the level of the volume of aggregates. The total volume of poured water corresponds to the volume of the void. The value of the void index is obtained by dividing the volume of the water poured by the volume of the aggregates after its moistening (since the volume of aggregates tends to decrease when wet). The result indicates the volume of lime required to fill the spaces of a specific amount of aggregates, which can be used as a starting point to determine the proportions of lime needed to obtain a stabilized mortar [29].

During the development of the experimental design of this investigation, the use of more porous aggregates was contemplated in order to obtain a sacrificial mortar more prone to saline crystallization, however; it was proposed to use both the proportion of lime resulting from the calculation of the void index and a proportion with an added third of aggregates in the mixture in order to impoverish it, thus increasing its porosity and make it more prone to the crystallization of salts compared to the first, "stabilized" mortar. It was estimated that impoverishing the mortar would be a sufficient measure to grant porosity to it, hence changing the aggregates in its composition was ruled out.

\section{Additives}

The nopal mucilage functions as a hydrocolloid: when dissolved or dispersed in water, produces a thickening or gelling of the mixture promoting water retention and the stabilization of emulsions. This characteristic delays the evaporation time of the water in the mixture and allows the formation of larger surface crystals during the setting process, which translates into a physically stronger surface. Moreover, since the nopal mucilage keeps the lime in suspension for a longer period of time, it allows the lime to remain manipulable and with a suitable consistency for its application, facilitating its management [31]. Finally, the addition of the mucilage to the lime improves its adherence to the materials it is applied to [32].

Accordingly, the use of nopal mucilage as an additive is proposed to constitute the sacrificial layer for Structure $B$, as its use grants greater plasticity and manageability to the mixture at the time of application, as well as better mechanical properties derived from a controlled setting process.

\section{Clay layer}

Desalination cycles are usually carried out employing poultices or cataplasms, and then the sacrificial layer is applied over to control the remaining salts. The operation mechanism of the poultices is similar to that of a sacrificial mortar, with the unique difference that they are applied for days or weeks and have no decorative or protective functions, but only that of desalination [33].

Organic materials poultices such as lignin are very thin for excessive amounts of salts, and there is a risk that they will not be able to receive all the salts, allowing, for this reason, their migration back into the substrate [34]. However, according to the study conducted by Auras [35], the extraction of salts is more effective with poultices made of clay minerals, as their fine pores produce a high capillary pressure, which translates into high suction when they are in contact with the architectural finishes. For these purposes, the use of diatomaceous earth, clays of attapulgite, sepiolite, montmorillonite or kaolinite is recommended.

With the objective of using the same principles of its use as a poultice in desalination processes, the placement of a layer of clays underlying the sacrificial mortar is proposed for the sacrificial layer of Structure B. With its application it is expected to obtain a higher absorption of humidity and salts towards the surface and therefore towards the sacrificial layer. The use of montmorillonite is proposed, since its structure and reduced electrostatic charge allows a greater inter-laminar space [36], which makes it more expandable, more plastic, cohesive and resistant in comparison with other clays.

\section{Interphase mesh}

The use of a mesh as an interphase between the original material and the sacrificial layer is proposed to separate the intervention as well as to denote it and allow its reversibility. Polypropylene, polyester and nylon are inert materials, which make up most of the geotextiles used as interphase in archaeological re-burial methods. It is important to mention that it is planned to use synthetic and non-organic interphase because the latter could react with humidity absorbing and containing it for a longer period of time, which, in addition to its organic composition, could promote the growth of microorganisms. Thanks to the placement of 
this mesh the sacrificial materials applied do not interact or interfere in any way with the original materials [37].

Polyamide 6.6, mostly known as Nylon, is characterized by its optimum mechanical properties: high impact resistance and high resistance to fatigue. Likewise, it has excellent resistance to common organic solvents and alkalis, whether strong or weak, and it is not attacked by microorganisms [37]. These qualities allow Nylon to be used as an interphase material for the sacrificial layer of Structure B given its ability to withstand the direct contact and the basicity of the lime.

Tricot tulle was chosen amongst the wide variety of nylon textiles due to the qualities of its fabric, allowing the passage of humidity and the necessary mechanical anchoring for the placement of the sacrificial layer and sufficiently closed to avoid direct contact of the original materials with those of the sacrificial layer.

\section{Experimentation}

\section{Preparation of the test samples}

Preparation of the base test sample

The experimental tests for the proposed sacrificial layers were carried out on $10 \mathrm{~cm} \times 10 \mathrm{~cm} \times 2 \mathrm{~cm}$ tezontle plate stones (extrusive igneous rock similar to some of the carved stone skulls on Structure B) prepared with a layer of "base" mortar that aimed at replicating the original stuccos that covered the reliefs of the stone skulls of Structure B. This mortar layer enabled a more realistic evaluation of the behavior of the different sacrificial layer models on substrates with similar characteristics to the original materials.

The mortar with which the original plasters were emulated consisted of basalt aggregates of $0.85 \mathrm{~mm}$ to $0.038 \mathrm{~mm}$ in a matrix of $60 \%$ of lime in accordance to the petrographic samples made to Structure B by Torres Trejo and Avelar Carmona in 2009 [38] as well as to Terry and Chilingar's comparative table of visual estimation of percentages [39] (Figures 4 and Figure 5). The application of this "original" mortar was carried out with a trowel obtaining average thicknesses of $2.67 \mathrm{~mm}$. Once the "original" mortar layer was set the different models of sacrificial layers to be evaluated were applied.

\section{Preparation of the different models of sacrificial layers}

As mentioned above, the analyzed variables were: the preparation of a balanced mortar obtained by calculating the void index; a weaker or impoverished one to evaluate its capillarity and resistance; the addition of nopal mucilage to the mortar to provide mechanical resistance; the placement of a layer of clay to increase the capillarity of the layer, and finally the use of an interphase mesh to denote the intervention (Table 1).

\section{- $\quad$ Obtaining the mortar with void index (I)}

The amount of lime added to the aggregates was determined by measuring the void index of a given volume of aggregates.

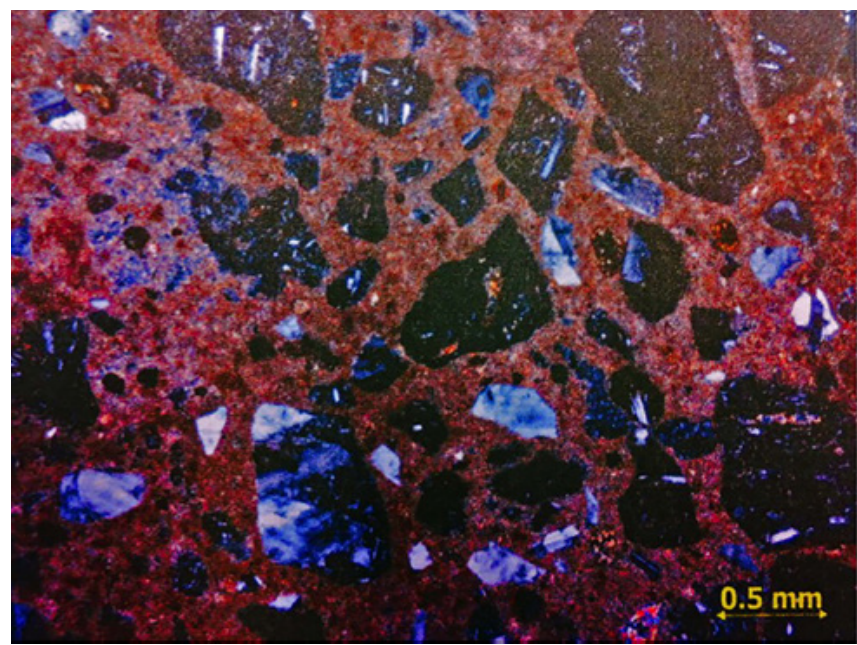

Figure 4. Structure B's stucco petrography by Torres Trejo and Avelar Carmona [38]
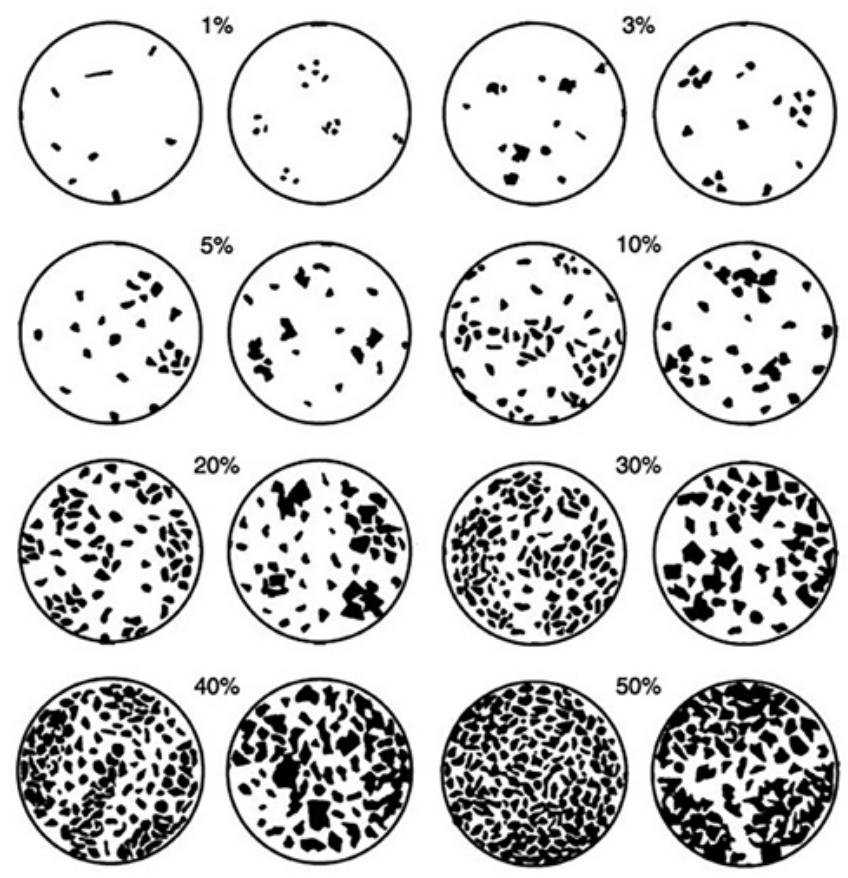

Figure 5. Terry and Chilingar's comparative table of visual estimation of percentages [39].

For this, the aggregates were placed in a container and water was added until they were saturated. It was left to rest for one hour until the water level remained constant to the volume of the aggregates. The poured water corresponds to the volume of the void between particles and it represents the necessary amount of lime to cover the given amount of aggregates [29].

\section{- $\quad$ Obtaining the impoverished mortar (I+)}

To obtain the mortar with one-third of added aggregates, one-third of the initial volume of aggregates was added to the mixture obtained in the previous step, resulting in a weaker mortar, poorer in lime, and therefore more porous.

\section{- Obtaining the nopal mucilage (B)}

The nopal mucilage was obtained from opuntia ficus indica cladodes. For the extraction of the mucilage, these were 
Table 1. Test samples designs obtained from the combination of the elements considered for the sacrificial layer for Structure B.

\begin{tabular}{|c|c|c|c|}
\hline With mesh & Without mesh & Clay with mesh & Clay without mesh \\
\hline IM (Void index with mesh) & I (Void index without mesh) & IAM (Void index with clay and mesh) & $\begin{array}{l}\text { IA (Void index with clay without } \\
\text { mesh) }\end{array}$ \\
\hline I+M (Impoverished with mesh) & I+ (Impoverished without mesh) & I+AM (Impoverished with clay and mesh) & $\begin{array}{l}\text { I+A (Impoverished with clay } \\
\text { without mesh) }\end{array}$ \\
\hline $\begin{array}{l}\text { IBM (Void index with nopal } \\
\text { mucilage with mesh) }\end{array}$ & $\begin{array}{l}\text { IB (Void index with nopal } \\
\text { mucilage without mesh) }\end{array}$ & $\begin{array}{l}\text { IBAM (Void index with nopal mucilage } \\
\text { with clay and mesh) }\end{array}$ & $\begin{array}{l}\text { IBA (Void index with nopal } \\
\text { mucilage with clay without mesh) }\end{array}$ \\
\hline $\begin{array}{l}\text { I+BM (Impoverished with nopal } \\
\text { mucilage with mesh) }\end{array}$ & $\begin{array}{l}\text { I+B (Impoverished with nopal } \\
\text { mucilage without mesh) }\end{array}$ & $\begin{array}{l}\text { I+BAM (Impoverished with nopal } \\
\text { mucilage with clay and mesh) }\end{array}$ & $\begin{array}{l}\text { I+BA (Impoverished with nopal } \\
\text { mucilage with clay without mesh) }\end{array}$ \\
\hline
\end{tabular}

sectioned longitudinally. The interior was scraped with a knife and the mucilage was only dragged without making incisions to it. The liquid obtained was passed through a strainer to avoid the presence of impurities such as fibers or solid sections.

The extracted mucilage was placed in several glass crystallizers, which were introduced in an oven at a constant $45^{\circ} \mathrm{C}$ to dehydrate it until obtaining a solid mucilage, which was later collected and weighed to obtain the necessary grammage to dilute it in distilled water at $5 \%$. Subsequently, for the rehydration process, the solid mucilage was placed in a glass beaker, the necessary quantity of distilled water was added to obtain the established concentration of $5 \%$, and it was mixed with a magnetic stirrer until the lumps were eliminated. Finally, before pouring it into the mortar mixture, it was strained one last time to avoid the presence of solid mucilage residues in the sacrificial layer (Figure 6).

\section{- Application of the clay layer (A)}

Montmorillonite was used for the test samples with a layer of clay in its constitution, as it is an expansive clay capable of containing high volumes of water. To prevent the clay from absorbing the water contained in the sacrificial mortar provoking it to crack during the drying and setting processes, it was decided to suspend the montmorillonite particles in water until they were saturated and it was later applied in a semi-liquid consistency in three or four layers, resulting in an average thickness of $0.43 \mathrm{~mm}$. Later, the sacrificial mortar was applied, while the clay layer remained humid.

\section{- $\quad$ Placement of the interphase mesh (M)}

For the test samples with the element of the interphase mesh in its composition, this was placed on the test samples generating tension at the edges to keep it as flat and tight as possible in order to avoid wrinkles and undulations that could physically destabilize the sacrificial layer.

From the combination of variables for the constitution of the sacrificial layers, 16 different models were obtained which were submitted by triplicate to each of the three tests procedures in order to corroborate or refute the results obtained. 144 samples were tested in total.

The experimental tests carried out in this investigation were based on those described in the 1998 ICCROM manual [40] and were performed on the $10 \mathrm{~cm} \times 10 \mathrm{~cm} \times 2 \mathrm{~cm}$ tezontle plate stones prepared with a $2 \mathrm{~mm}$ layer of lime stucco similar

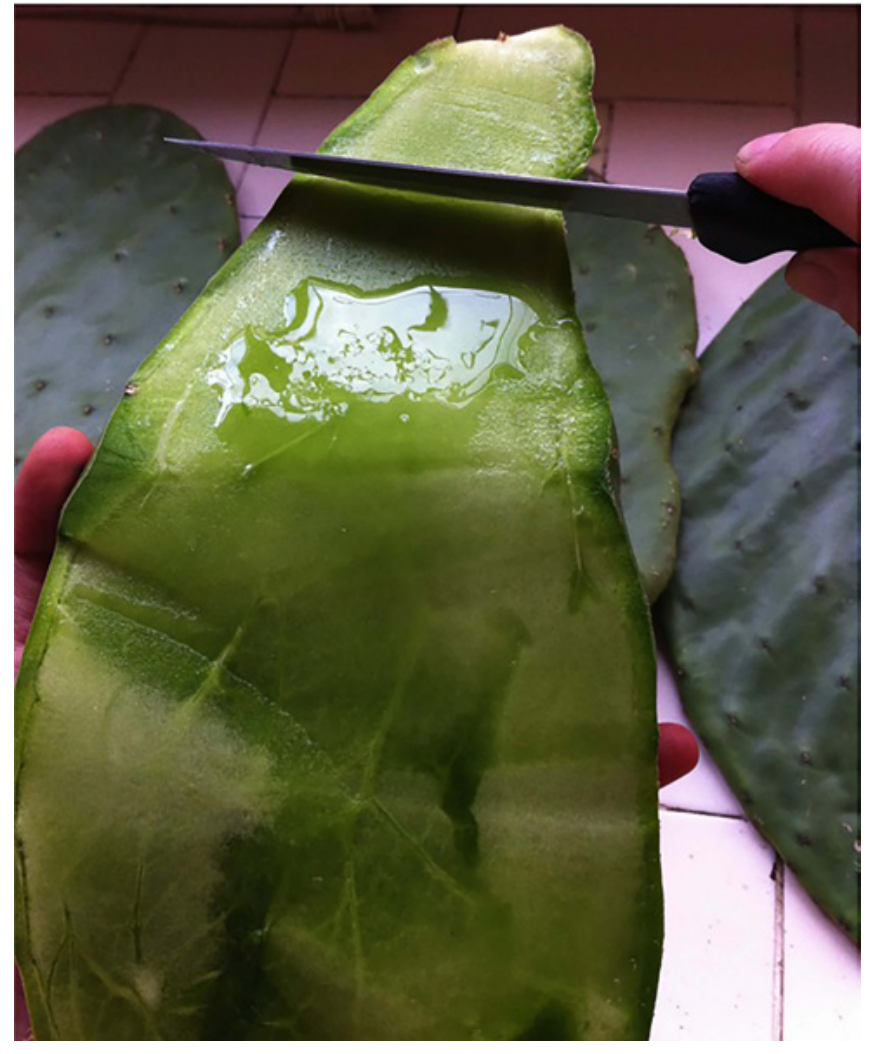

Figure 6. Nopal mucilage extraction.

to the ones observed on the original stone skulls of Structure $B$, and the different sacrificial layers designed, which were applied on each plate stone in a semi-liquid consistency using a brush. Three coats of $1 \mathrm{~mm}$ each were applied to each of the tezontle plate stones. Once the different designs of the sacrificial layer were set, the test procedures were initiated.

\section{Test procedures}

\section{Resistance to water abrasion test}

This test was carried out in order to emulate the impact of rainfall on Structure B and to identify the combination of elements that would make the sacrificial layer more resistant to water abrasion. During the procedure, the test samples were sprayed at a pressure of $55 \mathrm{psi}\left(38 \mathrm{~kg} / \mathrm{cm}^{2}\right)$ with an Evans air compressor at a $90^{\circ}$ angle at a distance of $5 \mathrm{~cm}$ for one hour in 15-minute lapses (Figure 7). Between each lapse, the 


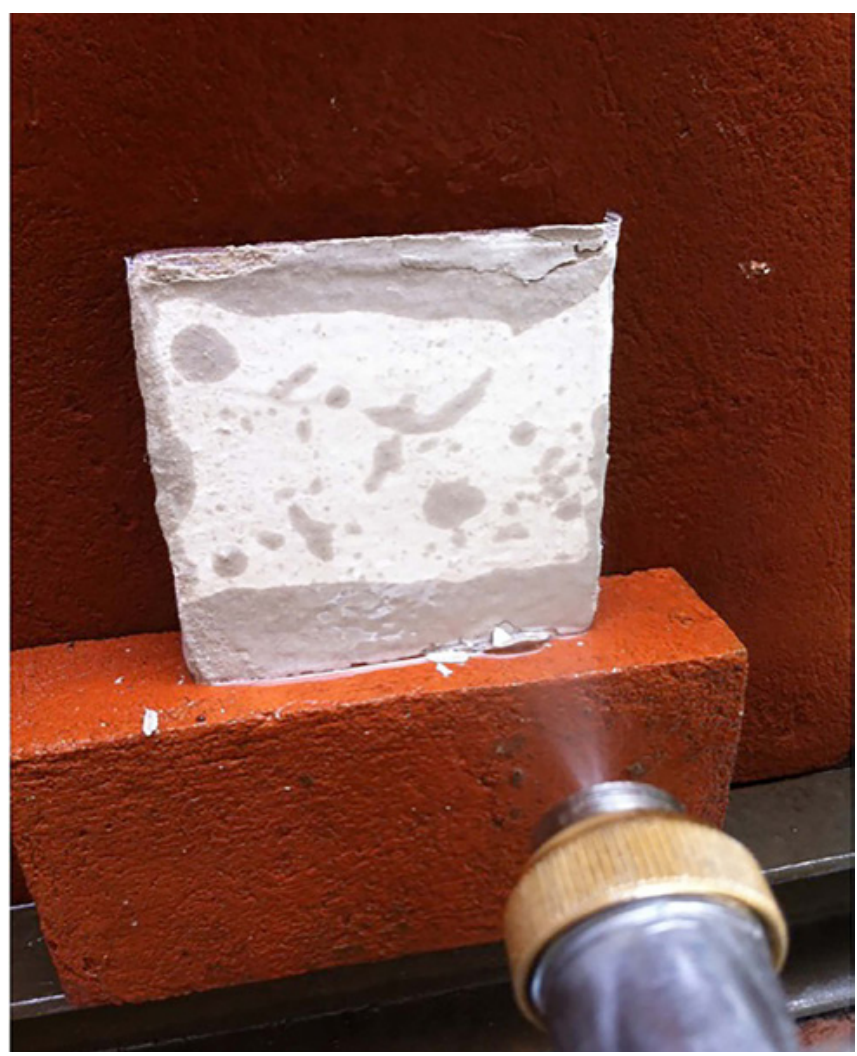

Figure 7. IBAM test sample during the resistance to water abrasion test.

abrasion levels were measured and after the elapsed time the maximum dimensions of the reached abrasion in the total time were recorded.

\section{Permeability test with Karsten tube}

This test aimed at simulating the absorption of humidity of the lime stuccos of Structure B, for which the Karsten Tube was placed on the surface of each test sample. The edges of the dome were then sealed with waterproof modeling clay or putty, and water was later poured into the cylinder to measure the amount of water absorbed by each test sample in 10-minute lapse (Figure 8).

\section{Resistance to crystallization of salts test}

The objective of this test was to measure the resistance of each sacrificial layer model to the crystallization of salts, as well as to determine if the clay layer acts as an absorbent layer and therefore a conductor of the salts towards the sacrificial layer. To perform this test the samples were placed in containers where the tezontle plate stones were in contact with a solution of the salts identified in Structure B: sodium chloride (at a concentration of $36 \mathrm{~g} / 100 \mathrm{ml}$ ); potassium nitrate (at a concentration of $36 \mathrm{~g} / 100 \mathrm{ml}$ ); anhydrous sodium sulfate (at a concentration of $16.2 \mathrm{~g} / 100 \mathrm{ml}$ ), and calcium chloride (at a concentration of $74.5 \mathrm{~g} / 100 \mathrm{ml}$ ) [41,42]. The test samples remained in the saline solution until it evaporated completely; the process was repeated twice. Afterwards, the samples were let to dry for two weeks for later observation.

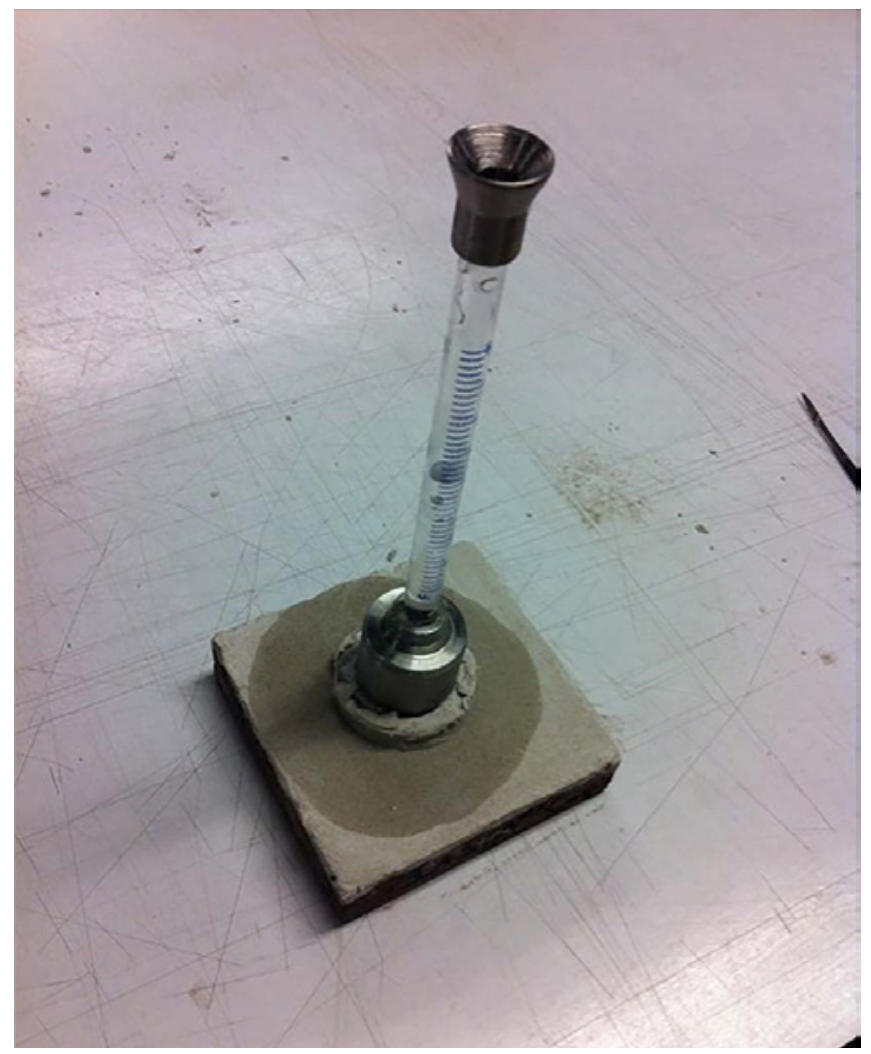

Figure 8. I+ test sample during the permeability test with Karsten tube.

\section{Results}

\section{Resistance to water abrasion test results}

After the execution of the test, irregularly eroded surfaces were obtained. Each was classified into four levels of incidence according to the visual assessment of the identified surface extension loss. The established classification includes (Figure 9):

- No apparent effect: No significant alterations were detected in the surface of the sacrificial layer nor in the stability of the samples subjected to the water abrasion test;

- Erosion: Minimal surface alterations that did not significantly decrease the thickness of the sacrificial layer. However, its texture was modified as a consequence of the mechanical impact of the water;

- Perforation: Punctual loss of the sacrificial layer leaving the stucco stratum exposed. Observe that the difference between this classification and the one referred to as "Loss" lies in the extent of the damage observed;

- Loss: Significant missing material in both the sacrificial layer and the stucco stratum.

According to the results of this test, the most resistant sacrificial layer model to water abrasion turned out to be the one constituted by a balanced mortar added with nopal mucilage without interphase mesh (IB), while greater affectation and abrasion was observed on weaker 

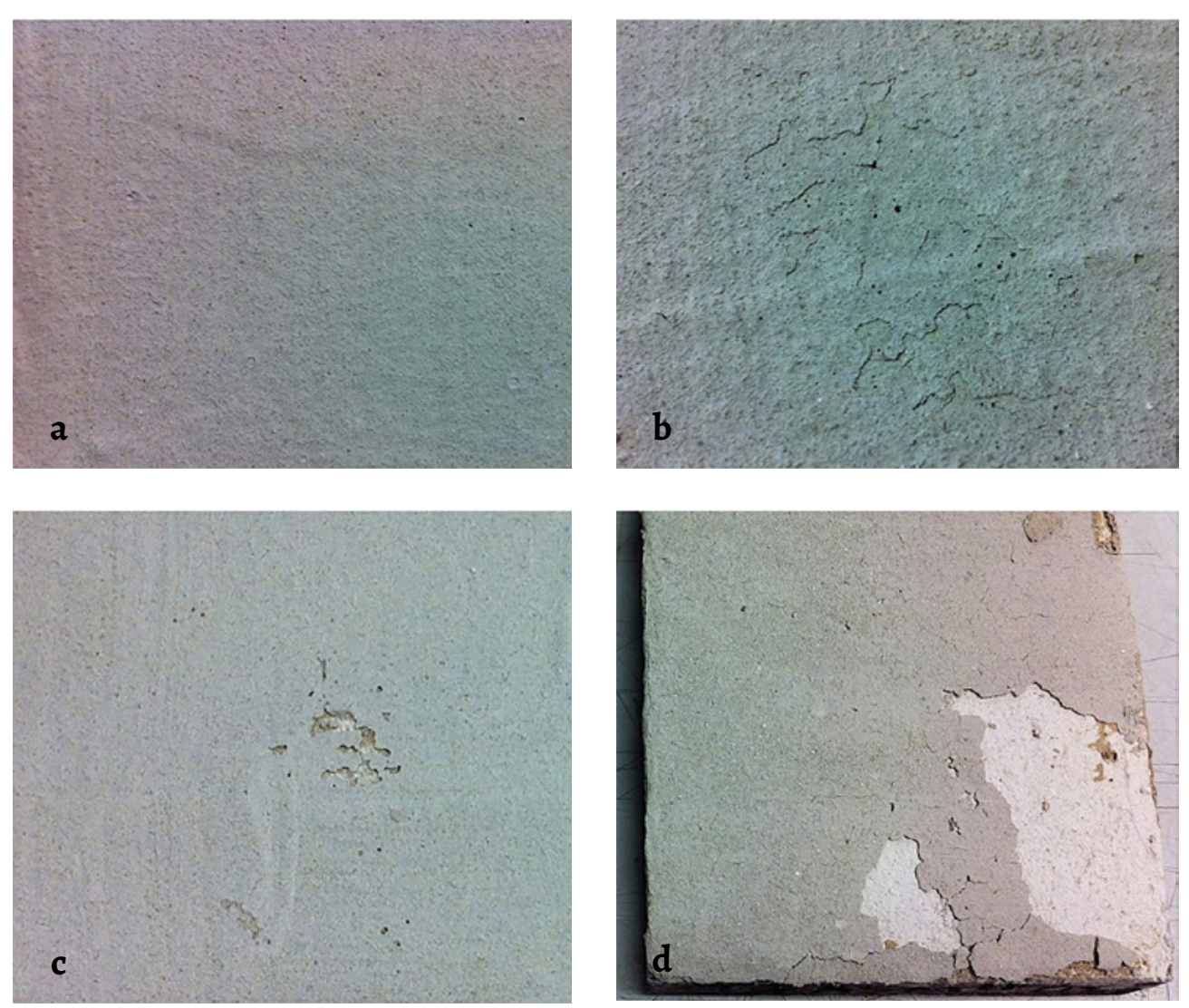

Figure 9. Observed behaviors on the test samples after the water abrasion test: $a$ ) no apparent effect (test sample IB); $b$ ) erosion (test sample I); $c$ ) perforation (test sample IA), d) loss (test sample I+A).

or impoverished mortars (I+), which were more fragile to mechanical action.

This test showed that the addition of nopal mucilage (B) to the mortar mixture does increase the resistance of the sacrificial layers because of the formation of large crystals due to humidity retention. This increase in the resistance was more evident in the test samples made with a weaker or impoverished mortar (I+). In the test samples without nopal mucilage, damage occurred quickly, while in those samples added with nopal mucilage (I+B) alteration by water abrasion was significantly delayed.

On the other hand, in the case of the test samples constituted by the weaker or impoverished mortar (I+) combined with the clay stratum (A), the sacrificial layer was seriously affected since the immediate disintegration of the clay layer was identified at the time of exposure to humidity. In this test, it was possible to establish that the clay layer does not provide additional protection or mechanical resistance, but instead damages the sacrificial layer due to the high reactivity of the clays in the presence of humidity.

\section{Permeability test with Karsten tube results}

In this test, the most permeable sacrificial layer was composed by the balanced mortar with nopal mucilage and an interphase mesh (IBM). Moreover, it was observed that the weaker or impoverished mortar (I+) did not increase the permeability of the sacrificial layer, as opposed to the expected behavior since the mixture turned out to be more porous but not more permeable, as the pores were not connected to each other. Likewise, the influence of the interphase mesh on the permeability of the systems was identified, as this property increased in most cases possibly because the mesh distributes humidity on the surface of the test sample thus increasing its permeability. On the other hand, in the test samples where the binomial claymesh is conjugated, the result is an almost impermeable surface (Figure 10).

\section{Resistance to crystallization of salts test results}

With the execution of this test it was possible to identify four different behaviors in the sacrificial layers upon the

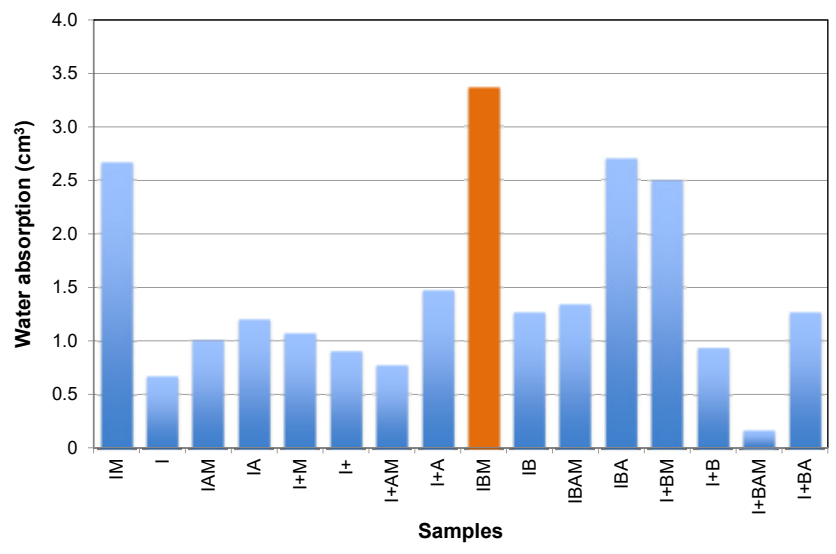

Figure 10. Average results from the Karsten tube permeability test. 
crystallization of salts based on their visual assessment (Figure 11):

- Pronounced bulging: significant deformation in the sacrificial layer, as well as fissures, detachments and even loss of material;

- Slight bulging: Insignificant bulges in small areas of the sacrificial layer without causing damage such as fissures or exposure of the underlying strata;

- Uniform crystallization: Very thin but uniform layer of crystallized salts on the sacrificial layer. It is important to mention that in this category no deformations were observed in any of the strata as a consequence of the differential concentration of the deposited salts;

- Minimal crystallization: Only small deposits of salt were observed on the sacrificial layer.

According to the results obtained from this test, the more resistant models of sacrificial layer to salt crystallization are those constituted by the balanced mortar with an interphase mesh (IM), a balanced mortar added with nopal

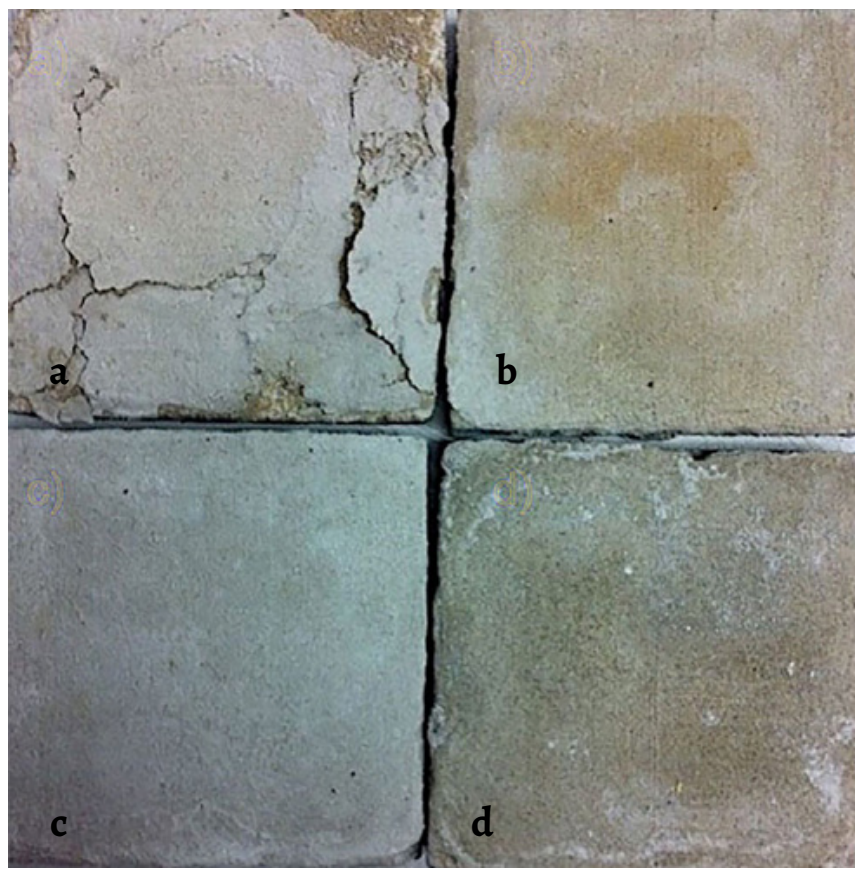

Figure 11. Resistance to crystallization of salts test: a) pronounced bulging; b) slight bulging; c) uniform crystallization; d) minimal crystallization. mucilage with a mesh interphase (IBM), and a weaker or impoverished mortar added with nopal mucilage without an interphase mesh (I+B).

As observed in the results of the permeability test with Karsten tube, weaker or impoverished mortars may be more porous but not necessarily more permeable. Hence, during the resistance to the crystallization of salts test, the kind of pores in the test samples failed to transfer the evaporation and salts towards the surface of the applied sacrificial layer, making this type of samples the ones with fewer alterations due to this condition. In this regard, it is important to mention that for treatments such as the extraction of salts from a structure by using a sacrificial layer method, mortars that are less dense and more porous in comparison with the original material are generally used, so deliberately impoverished mortars are used by adding porous aggregates to obtain additional spaces where the crystallized salts can be housed [33].

Thanks to this test it was possible to identify that the test samples with a clay layer are not suitable for transferring the crystallization products towards the surface of the sacrificial layer. Although the clay did absorb more water as they were the first samples to show surface crystallization, most of the salts at the end of the test ended up crystallizing in the clay layer and not in the sacrificial one, since they retained all the humidity in that stratum and failed to transmit it to the sacrificial layer. This circumstance caused the entire system to disintegrate. Also, the test samples with clay in their composition were the first to show alterations such as fissures, bulges and losses (Figure 12).

\section{Discussion}

According to the results of the tests it was resolved that the balanced mortar (I) added with nopal mucilage (B) with interphase mesh $(\mathrm{M})$ would be the best option of the sacrificial layers to be applied due to its performance shown in the tests, where it was little affected by the mechanical action of water abrasion, allowed the crystallization of the
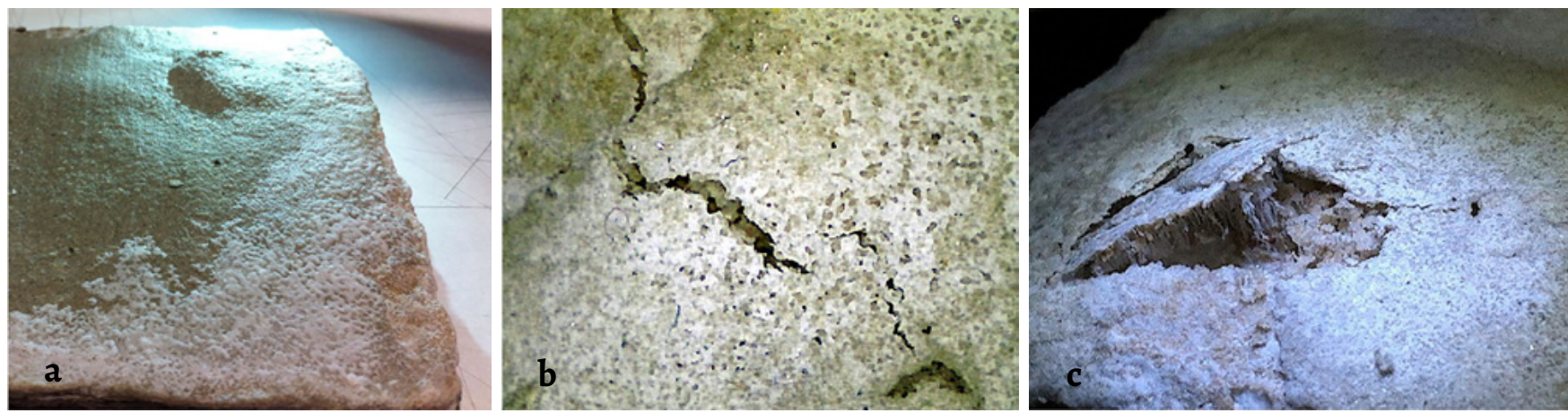

Figure 12.Test sample constituted by a balanced mortar added with nopal mucilage with a layer of clay without interphase mesh (IBA) after the resistance to crystallization of salts test: $a$ ) pronounced bulging due to the crystallization of salts on the clay stratum; $b$ ) fissures formed on the surface of the sample observed under Aven digital microscope at 20x; c) salt crystals formed in the clay stratum observed under Aven digital microscope at $5 \times$. 

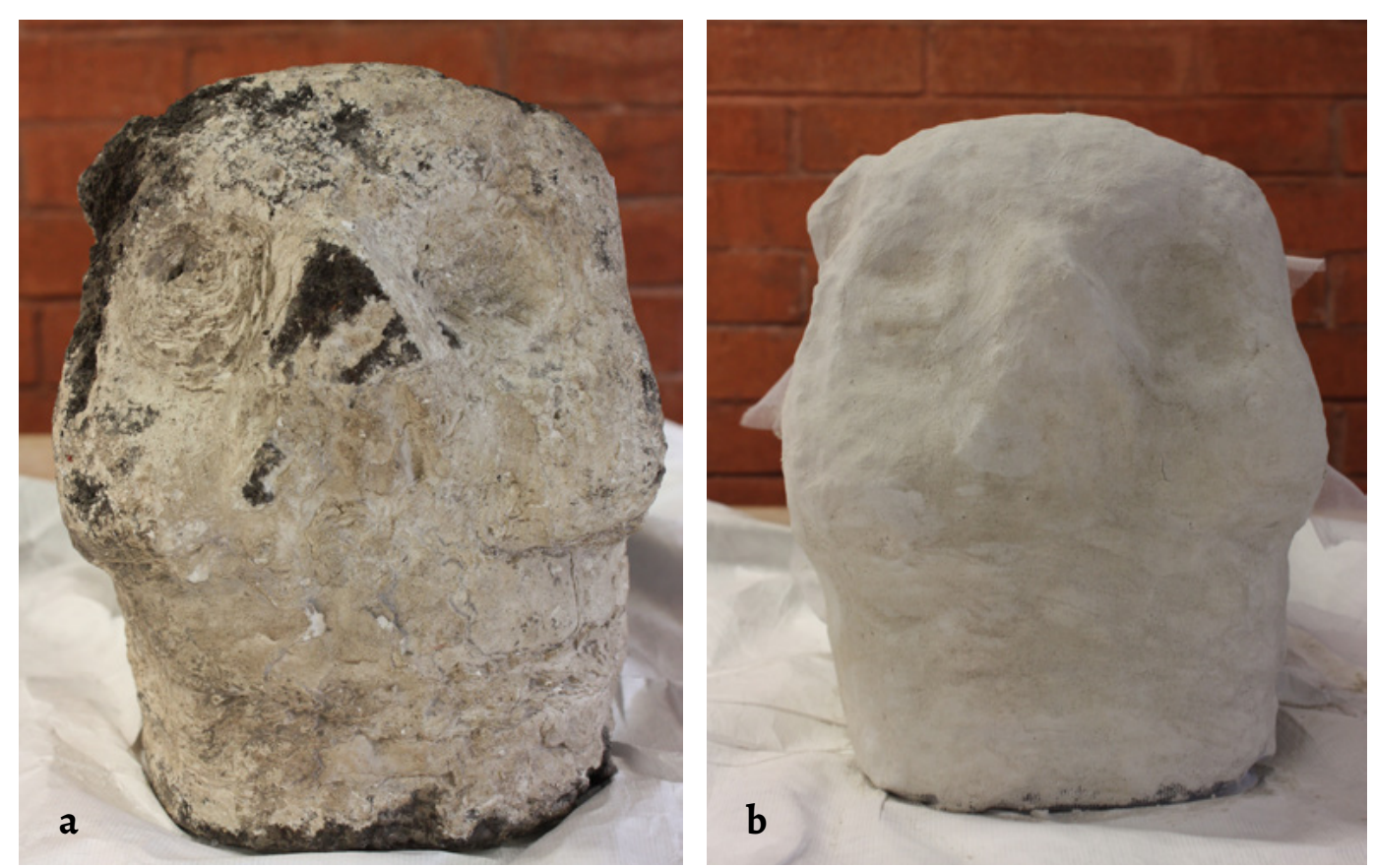

Figure 13. Application of sacrificial layer with stabilized mortar added with nopal mucilage with interphase mesh (IBM): a) stone skull before application; b) stone skull after application.

salts without showing macroscopic alterations and did not alter the permeability of the system.

It is considered that in this model of sacrificial layer the balanced mortar gave the mixture enough structure and the added lime with the contained void index made it sufficiently permeable, the nopal mucilage additive gave it resistance to mechanical impact as well as general resistance to contact with direct humidity as a result of the formation of larger crystals by slowed setting, also slightly increased its permeability. Similarly, the mesh increased the permeability of the system by uniformly distributing the humidity on the surface, in addition to ensuring reversibility to the intervention.

For this reason, the application of this sacrificial layer model on original material was carried out to corroborate whether said model respects the plastic qualities of the carvings as well as the stucco strata of the stone skulls. The application was carried out on stone skulls from the Archaeological Site of the Templo Mayor with similar characteristics to those observed on Structure B. It is important to mention that the specimens on which the sacrificial layers were applied were not submitted to any of the resistance tests, because its application pursued the sole objective of observing whether the sacrificial layer applied would affect the plastic qualities of the stone skulls and their multiple layers of stucco. Likewise, one of the requirements for the application of the sacrificial layers was that the stone skulls presented previous consolidation works so that if the elimination of the applied layers were necessary, the original stuccos would not be affected.

The nylon tricot tulle mesh was placed over the first stone skull to intervene. After the placement of the interphase mesh, the surface of the stone skull was moisturized with a sprinkler and then three layers of the balanced mortar added with nopal mucilage (IBM) were applied. The application was made using a soft hairbrush to make it as homogeneous as possible.

In this case the sacrificial layer was applied on the entire surface of the stone skull (including the stone) and not only on the stuccos since due to the pronounced reliefs of the stone skull, difficulties were encountered in placing and tightening the interphase mesh, so that cutting it in the sections of the exposed stone would generate the loss of tension and putting at risk the stability of the sacrificial layer.

The application of this sacrificial layer limited the visibility of the details of the carvings and the multiple strata of stucco due to the difficulty to achieve the tension of the mesh during the application of the sacrificial layer and at the same time respect the details of the stone skull (Figure 13). Moreover, the thickness of the mesh, added to that of the sacrificial mortar, caused the loss of details both in the stucco layers and in the carvings of the stone skull.

As a result, it was decided to apply a sacrificial layer with the same characteristics as the prior but without the interphase mesh (IB) on a new stone skull. In this case the sacrificial layer was applied directly on the stone skull to observe if the stucco layers remained evident after the application. Since in this occasion there would be no interphase mesh, the sacrificial layer was not applied directly on the stone but only on the areas with stucco. As before, the surface of the stone skull was moistened, and the sacrificial layer was applied with brushes.

In this occasion, it was observed that the particles of the mortar are housed between the stucco layers. Thus, 

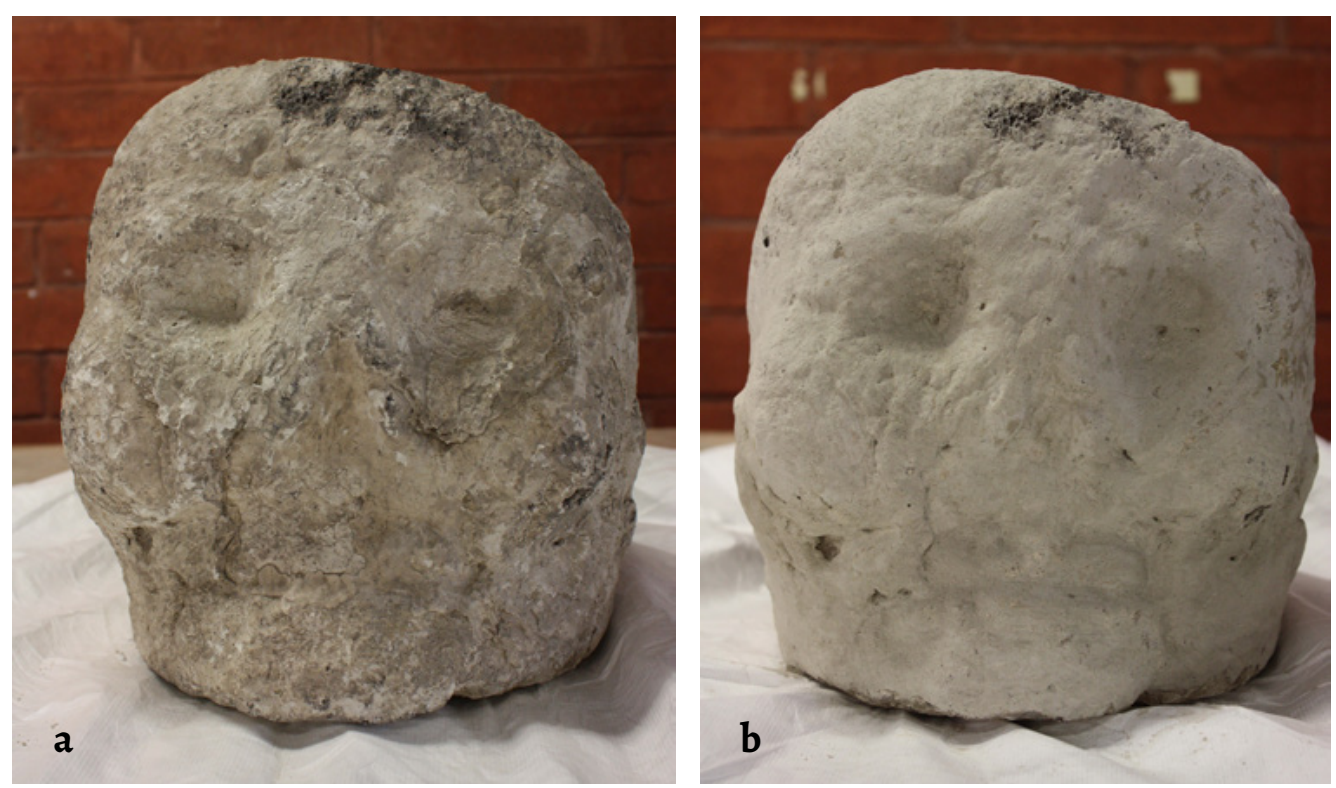

Figure 14. Application of sacrificial layer with stabilized mortar added with nopal mucilage without interphase mesh (IB): $a$ ) stone skull before application; b) stone skull after application.

after the application of three layers of the sacrificial layer the perception of the different strata ends up nearly lost and is perceived as one. However, in comparison with the previous case, the reliefs of the carvings remained visible and the image of the stuccos was homogenized (Figure 14). The application of the proposed sacrificial layer but without the interphase mesh allows the surface to be unified, which promotes the highlighting of the carvings on the stone.

From the application of the sacrificial layers on original material, it was found that the placement of the interphase

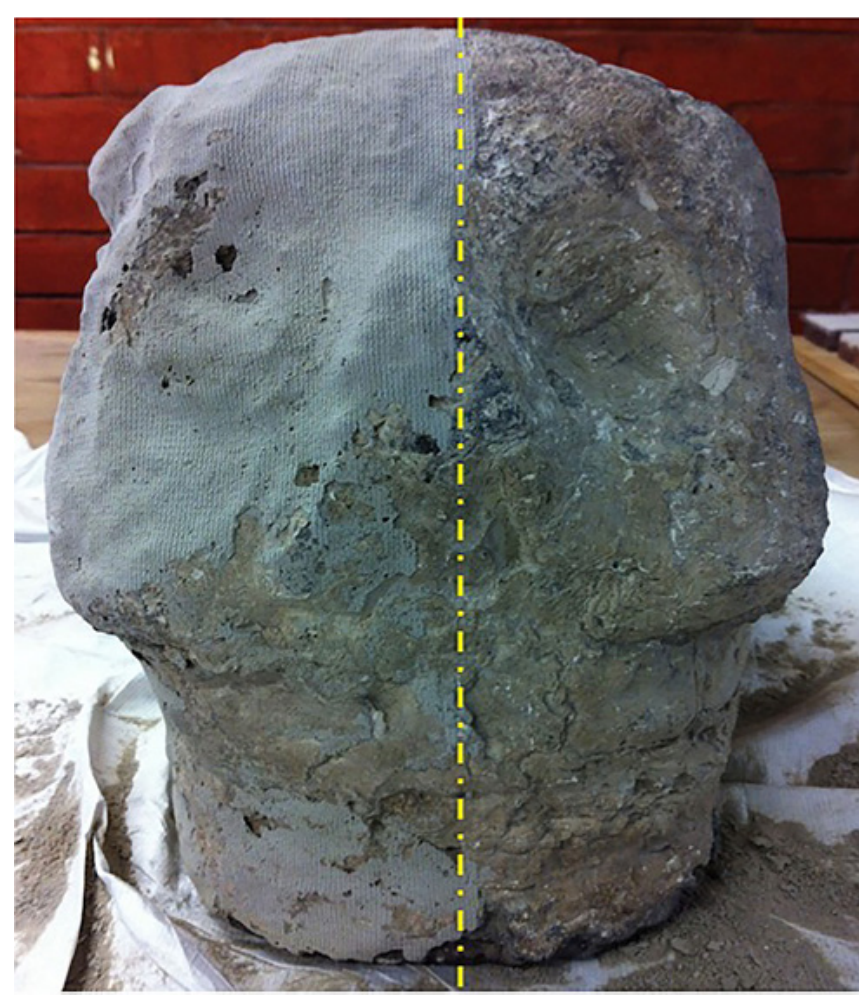

Figure 15. Stone skull half way through the sacrificial layer removal process. mesh in addition to hindering its application, causes the loss of many of the details of the stone carvings and stucco layers since for its correct operation the mesh requires to remain tense. Said tension, along with the thickness of the fabric, causes the interphase to obstruct the perception of the plastic qualities of the stone skulls (Table 2).

On the other hand, the application of the sacrificial layer without the element of the interphase mesh was more respectful of the carvings but, due to the aggregates of the mixture filling the spaces from the strata, slightly obfuscates the perception of the multiple stucco layers despite having been applied in a semiliquid consistency. This aspect can be beneficial because it homogenizes the stuccos causing the stone carvings to stand out.

Therefore, with the obtained results, the use of the interphase mesh for the sacrificial layer proposed for Structure B was ruled out, since its use is not relevant on relief surfaces.

It is important to mention that the elimination of the sacrificial layers applied directly on the original surface of the stone skulls was performed with dissection needles, spatulas and soft brushes and it was possible to accomplish without damaging the original stuccos (Figure 15), however it is estimated that in the case of applying the sacrificial layers directly on Structure B, its own alteration dynamics caused by the exposure to the weather would gradually eliminate them.

\section{Conclusions}

After evaluating the average behavior of each of the sacrificial layer models, the results of this investigation indicated that a balanced mortar (made in a suitable proportion between lime and aggregates) added with 
Table 2. Results behaviors of the tested samples.

\begin{tabular}{|c|c|c|c|}
\hline \multicolumn{2}{|l|}{ Samples } & \multicolumn{2}{|c|}{ Results } \\
\hline \multirow[t]{4}{*}{ With mesh } & IM & B & $\begin{array}{l}\text { Stable mortar has appropriate characteristics and mechanical resistance but is less resistant when compared } \\
\text { with a stable mortar added with nopal mucilage }\end{array}$ \\
\hline & $\mathrm{I}+\mathrm{M}$ & E & $\begin{array}{l}\text { Impoverished mortar was heavily affected during the water abrasion test, especially if conjugated with the } \\
\text { clay stratum }\end{array}$ \\
\hline & IBM & C & $\begin{array}{l}\text { Interphase mesh obfuscates the reading of the stone carvings and stucco layers, hence not appropriate to } \\
\text { apply on a surface with reliefs }\end{array}$ \\
\hline & $\mathrm{I}+\mathrm{BM}$ & $\mathrm{D}$ & $\begin{array}{l}\text { Impoverished mortar added with nopal mucilage is more resistant to the tests as a consequence of the added } \\
\text { mucilage but is less stable than a balanced mortar }\end{array}$ \\
\hline \multirow[t]{4}{*}{ Without mesh } & I & B & $\begin{array}{l}\text { Stable mortar has appropriate characteristics and mechanical resistance but is less resistant when compared } \\
\text { with a stable mortar added with nopal mucilage }\end{array}$ \\
\hline & I+ & E & $\begin{array}{l}\text { Impoverished mortar was heavily affected during the water abrasion test, especially if conjugated with the } \\
\text { clay stratum }\end{array}$ \\
\hline & IB & A & $\begin{array}{l}\text { Stable mortar added with nopal mucilage is resistant enough to endure Structure B's alteration dynamics and } \\
\text { does not affect the plastic qualities of the stone carvings and stuccos }\end{array}$ \\
\hline & $\mathrm{I}+\mathrm{B}$ & $\mathrm{D}$ & $\begin{array}{l}\text { Impoverished mortar added with nopal mucilage is more resistant to the tests as a consequence of the added } \\
\text { mucilage but is less stable than a balanced mortar }\end{array}$ \\
\hline \multirow[t]{4}{*}{ Clay with mesh } & IAM & $\mathrm{F}$ & $\begin{array}{l}\text { Clay stratum diminished permeability during the Karsten tube test and failed to transfer the humidity } \\
\text { towards the sacrificial layer causing the test sample to lose stability during the crystallization of salts test }\end{array}$ \\
\hline & $\mathrm{I}+\mathrm{AM}$ & E & $\begin{array}{l}\text { Impoverished mortar was heavily affected during the water abrasion test, especially if conjugated with the } \\
\text { clay stratum }\end{array}$ \\
\hline & IBAM & $\mathrm{F}$ & $\begin{array}{l}\text { Clay stratum diminished permeability during the Karsten tube test and failed to transferothe humidity } \\
\text { towards the sacrificial layer causing the test sample to lose stability during theocrystallization of salts test }\end{array}$ \\
\hline & $\mathrm{I}+\mathrm{BAM}$ & $\mathrm{D}$ & $\begin{array}{l}\text { Impoverished mortar added with nopal mucilage is more resistant to the tests as a consequence of the added } \\
\text { mucilage but is less stable than a balanced mortar }\end{array}$ \\
\hline \multirow[t]{4}{*}{ Clay without mesh } & IA & $\mathrm{F}$ & $\begin{array}{l}\text { Clay stratum diminished permeability during the Karsten tube test and failed to transfer the humidity } \\
\text { towards the sacrificial layer causing the test sample to lose stability during the crystallization of salts test }\end{array}$ \\
\hline & $\mathrm{I}+\mathrm{A}$ & E & $\begin{array}{l}\text { Impoverished mortar was heavily affected during the water abrasion test, especially if conjugated with the } \\
\text { clay stratum }\end{array}$ \\
\hline & IBA & $\mathrm{F}$ & $\begin{array}{l}\text { Clay stratum diminished permeability during the Karsten tube test and failed to transfer the humidity } \\
\text { towards the sacrificial layer causing the test sample to lose stability during the crystallization of salts test }\end{array}$ \\
\hline & $\mathrm{I}+\mathrm{BA}$ & $\mathrm{D}$ & $\begin{array}{l}\text { Impoverished mortar added with nopal mucilage is more resistant to the tests as a consequence of the added } \\
\text { mucilage but is less stable than a balanced mortar }\end{array}$ \\
\hline
\end{tabular}

nopal mucilage (IB), resists the mechanical action of water abrasion and allows the crystallization of salts without showing macroscopic alterations. Moreover, it does not alter the permeability of the system, making it a suitable alternative to protect the original lime stuccos of Structure B. This sacrificial layer model can deteriorate instead of the original materials in addition to respecting the plastic attributes of the stone carvings and stucco layers.

The investigation made it possible to identify that the use of montmorillonite clays as an intermediate layer between the original material and the sacrificial layer does not contribute to the migration of salts towards it but favors its crystallization on the clayey stratum causing bulges on the surface. Also, it was found that the use of weaker or impoverished mortars does not necessarily increase the permeability of the sacrificial layer and does not promote the crystallization of salts on the surface. Furthermore, these mortars suffer a decrease in its mechanical resistance to alteration factors such as rainfall, thus are not a viable option as a conservation treatment. In the results of the permeability test, it was observed that a weaker or impoverished mortar can be more porous but not more permeable according to the size of the pores and its capillary responses.

In this subject, it is important not to assume that an impoverished mortar benefits in all cases to the process of evaporation, while it is important to consider that impoverishing a mortar can compromise its physical stability and that of the sacrificial layer system. Finally, the addition of nopal mucilage to the mortar proved to significantly increase its resistance to the mechanical action of water abrasion even in the impoverished test samples.

It is worth mentioning that there is not and should not be a general formulation for the sacrificial layer, being important to have a throughout understanding of the structure or object in hands, environmental conditions and expected alterations. This investigation if essential not only to identify the real needs of the structure in hands but also to set the 
objectives to be achieved with that sacrificial layer system for its long-term conservation. The qualitative methodology proposed in this study included the characterization and categorization of the results through the establishment of visual assessment parameters, being, for this reason, recommended to be applied in different contexts. Finally, the fact no specialized equipment or tools are need makes this methodology easy to adjust and replicate to other case studies [43].

\section{Acknowledgements}

This research is derived from the Proyecto para la conservación del Edificio B "Altar de Cráneos" de la Zona Arqueológica de Templo Mayor, developed since 2009 by the Seminario Taller de Restauración de Obra Mural of the National School of Conservation, Restoration and Museography "Manuel del Castillo Negrete" along with the Museum and archaeological site of Templo Mayor. Many thanks to Leonardo López Lujan, Patricia Ledesma, María Barajas, Jaime Torres, Martha Tapia, Martha Lameda, Marlene Sámano, Irlanda Fragoso, Diana Medellín, Judith Alva, Abigail Flores, Alejandra Lechuga, Vanessa Castillo and Mirell Betanzo.

\section{REFERENCES}

1. Ezcurra, E.; Mazari, M.; Pisanty, I.; Aguilar, A., La Cuenca de la Ciudad de México, Fondo de Cultura Económica, Mexico (2006).

2. Fragoso, I.; Sámano, M., 'Proyecto para la conservación del Edificio B Altar de Cráneos', Escuela Nacional de Conservación, Restauración y Museografía, Mexico (2010).

3. Koller, M., Sacrificial Layers for Conservation of Stone. Theory and Practice. ICCROM, Venice (1997).

4. Alonso-Olvera, A.; Meehan Hermanson, P., 'Los recubrimientos de protección y sacrificio como alternativa de conservación in situ para monumentos históricos y arqueológicos', in La Cal. Historia, Propiedades y Usos, ed. L. B. Pingarrón \& I. S. Villaseñor, Instituto de investigaciones antropológicas: UNAM, DF, Mexico (2013) 205-231.

5. Aguilar Gutiérrez, M. A.; Alcántara Mejorada, M.; Benavides Soriano, K.; Castellanos Frías, I. A.; Egea, A., Fernández, J.; Flores, R.; Giraldo, I.; Gutiérrez, C.; Hoyos, S.; Jiménez, K.; Lemoine, I.; Lira, D.; Milán, A.; Morales, A.; Palomino, H.; Peláez, A.; Ramirez, A.; Rojas, R.; Ruiz, M.; Ruiz, R.; Téllez, C.; Téllez, L.; Torres, M.; Vásquez, A.; Vázquez, G.; Vega, D., 'Proyecto Palenque ENCRyM 2014: Informe de las actividades de restauración', ENCRyM-INAH, Mexico (2014).

6. Alonso-Olvera, A.; Meehan Hermanson, P., 'Primer informe de los trabajos de conservacion y restauración de los elementos decorativos de la acrópolis de la zona arqueológica de Ek'Balam, Yucatán. 1. ${ }^{a}$ temporada de trabajo', CNCPC-Centro INAH Yuctán-INAH, Mexico (2001).

7. Arano Recio, D. E.; Jáidar Benavides, Y.; Muerza Avendaño, B. A.; Ruiz Martín, M.; Cárdenas Carbajal, J.; Guzmán Solano, M.; Hernández Romero, P., 'Informe de los trabajos de conservación del friso de estuco de Balamkú, Campeche', CNCPC-ENCRyM-INAH, Mexico (2000).

8. Brown, R. B.; Sandoval, B.; Orea, M. H., 'La protección y conservación de las estructuras de adobe en Paquimé, Casas Grandes, Chihuahua', CNCPC-INAH, Mexico, (1990).

9. Chan Verduzco, J. R., 'Conservación de la zona arqueológica de Balamkú, Campeche', CNCPC-INAH, Mexico (1991).
10. García Solis, C. A., 'Restauración de Becán y Chicanná, Campeche. Informe de actividades', CNCPC-INAH, Mexico (2001).

11. García Solis, C. A.; Valencia Pulido, S. B., 'Proyecto Chicanná, Campeche', CNCPC-INAH, Mexico (1996).

12. García Solis, C. A.; Valencia Pulido, S. B., 'El deterioro de piedra en la zona arqueológica de Chicanná, Campeche y una propuesta para su conservación', Bachelor dissertation, ENCRyM-INAH, Mexico (1997).

13. García Solís, C.; Vázquez Veiga, A., 'Informe de las actividades del proyecto de conservación de los elementos modelados en estuco y pintura mural de Mayapán, Yucatán', CNCPCENCRyM-INAH, Mexico (2010).

14. García Vierna, V., 'Informe de las labores realizadas en las zonas arqueológicas de Becán y Chicanná', CNCPC-INAH, Mexico (2000).

15. García Vierna, V., 'Proyecto para la intervención del friso de Balamkú, Campeche', CNCPC-INAH, Mexico (2003).

16. Jáidar Benavides, Y.; Ruiz Martín, M., 'Proyecto arqueológico de Becán, Campeche. Informe annual', CNCPC-INAH, Mexico (2004).

17. Jaidar Benavides, Y., 'Conservación emergente del mascarón de estuco de la estructura $\times$ del sitio arqueológico de Becán, Campeche', CNCPC-INAH, Mexico (2010).

18. Magar Meurs, V.; Meehan Hermanson, P., 'Proyecto de conservación e investigación de pintura mural en la costa oriental de Quintana Roo. Informe de temporada de campo', CNCPC-INAH, Mexico (2012).

19. Orea Magaña, H.; Sandoval, B.; Espinoza Chávez, A., 'Anteproyecto de restauración y conservación de los restos arqueológicos de la zona arqueológica de Paquimé, Chihuahua', CNCPC-INAH, Mexico (1993).

20. Orea Magaña, H.; Sandoval, B., 'Informe de los trabajos de conservación de materiales arqueológicos. Proyecto especial Xochicalco', CNCPC-INAH, Mexico (1994).

21. Rivero Chong, R., 'Informe parcial del proyecto de conservación del Templo de Quetzalcóatl', CNCPC-INAH, Mexico (2004).

22. Rivero Chong, R., 'Proyecto de conservación del Templo de Quetzalcóatl', CNCPC-INAH, Mexico (2004).

23. Rivero Chong, R. 'Anteproyecto de conservación del Templo de Quetzalcóatl. $2^{\text {a }}$ temporada', CNCPC-INAH, Mexico (2005).

24. Rivero Chong, R., 'Proyecto de conservación del templo de Quetzalcóatl. $3^{a}$ temporada', CNCPC-INAH, Mexico (2006).

25. Rivero Chong, R., 'Proyecto de restauración del Templo de Quetzalcóatl', CNCPC-INAH, Mexico (2006).

26. Severiano Flores, V. G., 'Proyecto de conservación del Templo de Quetzalcóatl, Teotihuacán', CNCPC-INAH, Mexico (2009).

27. Severiano Flores, V. G., 'Proyecto de conservación del Templo de Quetzalcóatl, Teotihuacán', manuscript, CNCPC-INAH, Mexico, (2011).

28. Alejandre Sánchez, F., Historia, Caracterización y Restauración de Morteros, Universidad de Sevilla, Sevilla, Spain (2002).

29. The Preservation of Historic Architecture: the U. S. Government's Official Guidelines for Preserving Historic Homes, The Lyons Press, Guilford, Connecticut (2004).

30. Henry, A.; Stewart, J., Practical Building Conservation: Mortars, Renders \& Plasters, Ashgate, Farnham (2011).

31. Martínez Camacho, F., 'El mucílago de nopal como alternativa 
para la consolidación de adobe. Estudio de un caso: el Templo de la Antigua Misión de Nuestra Señora del Pilar y Santiago de Cocóspera, Sonora', bachelor dissertation, Escuela Nacional de Conservación, Restauración y Museografía, Mexico (2009).

32. Cruz Flores, S., 'El mucílago de nopal como aditivo de las pastas de cal empleadas en conservación', in La Cal. Historia, Propiedades y Usos, ed. L. B. Pingarrón \& I. S. Villaseñor, Instituto de investigaciones antropológicas: UNAM, Mexico (2013) 185-204.

33. Young, D., Salt Attack and Rising Damp. A Guide to Salt Damp in Historic and Older Buildings, South Australian Department for Environment and Heritage, Adelaide (2008).

34. Grave, J.; Krage, L.; Lusis, R.; Vitina, I., 'Desalination of brick masonry and stone carvings in Capitulum hall of Riga Dome Cathedral', IOP Conference Series: Materials Science and Engineering 25 (2011), https://doi. org/10.1088/1757-899X/25/1/012004.

35. Auras, M., Poultices and Mortars for Salt Contaminated Masonry and Stone Objects, Institute for the conservation of stone, Mainz, Germany (2008).

36. Domínguez, J.; Schifter, I., Las Arcillas: El Barro Noble. Fondo de Cultura Económica, Mexico (1992).

37. Kavazanjian, E. J., 'The use of geosynthetics for archeological reburial', Conservation and Management for Archeologial Sites 6(34) (2004) 377-393, https://doi.org/10.1179/135050304793137847.

38. Torres Trejo, J.; Avelar Carmona, A. L., 'Informe del análisis realizado a tres muestras de materiales constructivos procedentes del Edificio B del Templo Mayor de Tenochtitlan', Laboratorio de Geología, ENCRyM-INAH, Mexico (2009).

39. Terry, R.; Chilingar, G., 'Sumary of "Concerning some additional aids in studying sedimentary formations" by MS Shvetsov', Journal of Sedimentary Petrology 25 (3) (1955) 229-234.

40. Teutonico, J., A Laboratory Manual for Architectural Conservators, ICCROM, Rome (1988).

41. Sánchez Ibarrola, A., 'Reporte de identificación de sales presentes en el Edificio B de Templo Mayor', ENCRyM-INAH, Mexico (2011).

42. Baglioni, P.; Giorgi, R., 'Reporte de los resultados de los análisis con espectroscopía infrarroja del Tzompantli en el sitio arqueológico de Templo Mayor', University of Florence (2010).

43. Carmona, E., 'Propuesta para la elaboración de capas de sacrificio para el Edificio B ('Altar de Cráneos') del Templo Mayor', Bachelor dissertation, ENCRyM-INAH, Mexico (2017)
RECIBIDO: 2018.11 .30

REVISTO: 2019.4 .5

ACEPTADO: 2019.4.7

ONLINE: 2019.5.14

\section{(1) (1) (3)}

This work is licensed under the Creative Commons Attribution-NonCommercial-NoDerivatives 4.0 International License. To view a copy of this license, visit http://creativecommons.org/licenses/by-nc-nd/4.o/deed.en. 